\title{
MODEL KONSTRUKSI MAKNA PERAN DAN POSISI PEREMPUAN INDONESIA PELAKU KAWIN CAMPUR
}

\author{
Benazir Bona Pratamawaty ${ }^{1}$, Deddy Mulyana ${ }^{2}$, Dadang Sugiana ${ }^{3}$ \\ Fakultas Ilmu Komunikasi Universitas Padjadjaran \\ J1. Raya Bandung-Sumedang KM21, Jatinangor, Jawa Barat \\ Telp. (022) 84288828 \\ Email: benazir.bona@unpad.ac.id ${ }^{1}$, deddy.mulyana@unpad.ac.id ${ }^{2}$, \\ dadang.sugiana@unpad.ac.id ${ }^{3}$
}

\begin{abstract}
This study aims to explore marriage between Indonesian women and the western men (laki-laki bule) from western culture and to describe the meaning of role and position of Indonesian women married with western men. Individual perspective on the role and gender position in marriage life is mostly influenced by neighbours, community, and family. The process of interpreting the role and gender position for Indonesian women is a part of community construction. This research deploys phenomenological perspective, particularly symbolic interactionism and the theory of the social construction of reality. Data have been collected by in-depth interviews and observation to seven Indonesian women married to western men in Jakarta selected through snowball sampling. This research found a construction meaning model related to the role and position of Indonesian women doing mix marriage. Through interaction with their husband, the informants define their role and position in marriage life which is inline with equality principle done by their husband including four different equality meaning, such as partial equality, natural equality, absolute equality, and pragmatic equality. The contribution of this study is to provide a model of construction of meaning on the role and position of Indonesian women doing mixed marriage in family and community.
\end{abstract}

Keywords: Cross-cultural Marriage, Intercultural Communication, Phenomenology, Symbolic Interactionism

\begin{abstract}
Abstrak
Penelitian ini difokuskan pada perkawinan antara perempuan Indonesia dan laki-laki bule yang berasal dari budaya Barat. Tujuan penelitian untuk mendeskripsikan makna peran dan posisi diri perempuan Indonesia yang menikah dengan laki-laki bule. Perspektif individu mengenai peran dan posisi gender dalam sebuah perkawinan sangat dipengaruhi oleh lingkungan sekitarnya, masyarakat, terutama keluarga. Proses pemaknaan peran dan posisi gender bagi perempuan Indonesia ini merupakan bagian dari bentukan masyarakat. Penelitian ini menggunakan perspektif fenomenologi, khususnya interaksi simbolik dan teori konstruksi sosial atas realitas. Pengumpulan data dilakukan dengan wawancara mendalam dan pengamatan terhadap tujuh informan. Informan penelitian ditentukan menggunakan teknik snowball sampling. Hasil penelitian menemukan model konstruksi makna peran dan posisi perempuan indonesia pelaku kawin campur. Melalui interaksi informan dengan sang suami, informan kemudian mendefinisikan peran dan posisi diri informan dalam kehidupan perkawinan sejalan dengan prinsip kesetaraan yang diberlakukan oleh suami yang terbagi atas empat pemaknaan kesetaraan yang berbeda, yakni setara parsial, setara kodrati, setara mutlak, dan setara pragmatis. Kontribusi penelitian ini adalah penemuan model konstruksi makna peran dan posisi perempuan dalam keluarga dan masyarakat bagi perempuan Indonesia pelaku kawin campur.
\end{abstract}

Kata Kunci: Fenomenologi, Interaksi Simbolik, Komunikasi Lintasbudaya, Perkawinan Lintasbudaya

\section{Pendahuluan}

Perkawinan antara dua orang dengan dua latar belakang budaya yang berbeda memiliki tantangan yang lebih besar daripada perkawinan antara dua orang dengan latar belakang budaya yang sama. Fontaine dan Dorch (1980) dalam Gudykunst dan Kim (1997: 331) menyatakan bahwa perkawinan lintasbudaya lebih bermasalah daripada perkawinan intraetnik. Samovar, Porter, 
dan McDaniel (2010: 284) mengungkapkan bahwa banyak masalah yang diasosiasikan dengan pernikahan, namun ketika dua orang dari dua budaya yang berbeda menikah, masalah yang mungkin timbul pun bertambah banyak. Graham, Moeai, dan Shizuru (1985) juga menyatakan bahwa terdaarapat banyak masalah eksternal dalam perkawinan lintasbudaya daripada intrabudaya, meski keduanya sama-sama puas dengan pernikahan mereka. Lebih jauh dijelaskan bahwa keberhasilan perkawinan lintasbudaya tergantung pada kemampuan untuk menyesuaikan diri satu sama lain.

Perkawinan lintasbudaya atau yang sering disebut dengan kawin campur yang terjadi di Indonesia sebagian besar terdiri dari perkawinan antara perempuan Indonesia dengan laki-laki WNA. Berdasarkan pencatatan pegawai catatan sipil Provinsi DKI Jakarta, jumlah perempuan Indonesia yang menikah dengan laki-laki bule selalu lebih banyak daripada jumlah perempuan Indonesia yang menikah dengan laki-laki WNA dari keturunan ras lainnya. Bule adalah istilah yang digunakan orang Indonesia sejak zaman penjajahan dahulu yang merujuk pada orang berkulit putih layaknya albino. Istilah bule berasal dari kata bulai, yang di dalam Kamus Besar Bahasa Indonesia Edisi III memiliki arti orang berkulit putih (terutama orang Eropa dan Amerika). Penggunaan kata bule dirujukkan kepada orang asing yang memiliki ciri-ciri fisik berkulit putih, dengan rambut berwarna (pirang, cokelat) dan bola mata berwarna-warni. Dengan kata lain, istilah bule tersebut merujuk pada orangorang dari golongan ras Kaukasia, yakni ras yang banyak menghuni negara-negara Barat. Tak heran jika istilah orang bule sering diidentikkan dengan istilah orang Barat. T.T. Anh (1984: 5) menyamakan negara-negara Barat dengan negara-negara Eropa Barat, Amerika Serikat, Kanada, Australia, dan Selandia Baru. Berdasarkan hal tersebut, yang dimaksud dengan orang bule dalam penelitian ini adalah orang kulit putih atau ras Kaukasia yang berasal dari negaranegara Eropa Barat, Amerika Serikat, Kanada, Australia, dan Selandia Baru.

Pada sebuah perkawinan lintasbudaya penyesuaian diri dengan pasangan menjadi krusial. Di sinilah komunikasi memainkan peranan pentingnya. Perempuan Indonesia yang bersuamikan laki-laki bule tidak hanya harus beradaptasi dengan karakter sang suami, namun juga dengan latar belakang budaya yang dibawa oleh sang suami. Penggunaan bahasa dalam komunikasi yang dilakukan antarpasangan pun kemudian menjadi sangat penting. Porter dan Samovar (1982) dalam Mulyanadan Rakhmat(2010:23)menyebutkan bahwa perbedaan-perbedaan antara budaya Barat dan budaya Asia (Indonesia termasuk di dalamnya) merupakan contoh utama perbedaan budaya yang maksimum. Kedua budaya tersebut berada dalam kutub yang berlawanan dan memiliki perbedaan yang tinggi. Perbedaan latar belakang budaya tersebut sangat mempengaruhi cara pandang, pola pikir, serta sistem nilai yang dianut individu.

Samovar,Porterdan McDaniel(2010: 284) menyebutkan bahwa salah satu hal rumit dalam kehidupan perkawinan lintasbudaya adalah perbedaan peran gender. Bagaimana seorang laki-laki bule memaknai peran gender dalam 
kehidupan berkeluarga dan bermasyarakat tentunya berbeda dengan bagaimana perempuan Indonesia memaknainya.

Goode seperti dikutip Kusumastuti (2007: 145)menyatakanbahwaperbedaandalamperan gender sangat menonjol dalam pembagian kerja menurut jenis kelamin. Pada semua masyarakat tugas-tugas berbeda diberikan kepada perempuan dan laki-laki, namun ada juga yang dapat dikerjakan oleh keduanya. Samovar dkk (2011: 75) menjabarkan bahwa salah satu pola keluarga yang penting dan ditemukan dalam setiap kebudayaan adalah ajaran tentang peran gender yang berlaku. Seperti yang dinyatakan Wood dalam Samovar dkk (2011: 75), "Diantara orang-orang yang mempengaruhi identitas gender kita, orangtua merupakan faktor yang utama". Pembelajaran mengenai peran gender yang diterima secara budaya dimulai sejak seorang bayi lahir dengan mengumumkan bayi tersebut laki-laki atau perempuan. Seperti yang diamati oleh Robbins dalam Samovar dkk (2011), "Bayi diberi nama sesuai dengan gender, diberi baju atau warna baju yang pantas, dan berbicara dengan bahasa yang serasi dengan gender".

Galvin dan Cooper menawarkan sinopsis berikut dengan menyimpulkan penelitian tentang sosialisasi gender : pada masyarakat, laki-laki diasosiasikan dengan berhasil, agresif, seksual, dan percaya diri, sedangkan perempuan diasosiasikan dengan sensitif, tidak mandiri, dan berhubungan dengan penampilan. Seperti yang dikemukakan Coles dalam Samovar dkk (2011), "Ekspektasi gender yang dibentuk secara sosial untuk perempuan dan laki-laki sering diterjemahkan dalam pengalaman dan peran yang berbeda selama hidup". Pemahaman akan ekspektasi itu menawarkan petunjuk bagaimana suatu interaksi berlangsung. Setiap individu memiliki ekspektasi yang berbeda terhadap pasangannya, baik sebagai suami maupun istri. Bagi perempuan Indonesia yang bersuamikan laki-laki, latar belakang budaya Indonesia yang dibawanya tentu saja mempengaruhi ekspektasinya atas peran sang suami di rumah dan bagaimana perannya sendiri sebagai seorang istri dan seorang ibu.

Samovar dkk (2011: 76) menjelaskan bahwa perbedaan peran gender ditemukan dalam budaya Jepang, Vietnam, Cina, dan Korea. Hal yang menarik dari peranan gender dalam budaya Asia pada umumnya, menurut Hendry dalam Samovar dkk (2011: 76), adalah walaupun sistem keluarga memandang lakilaki posisinya lebih tinggi daripada perempuan, "tugas untuk memerhatikan keluarga umumnya jatuh pada perempuan, baik ketika sakit, terluka, atau ketika tua". Sementara itu, menurut Adeney (2004: 301) masyarakat Indonesia sendiri bersifat patriarkal di mana perempuan pada umumnya turun-temurun menunjukkan penghormatan mereka terhadap laki-laki. Kaum perempuan kadang-kadang dipandang bukan cuma lebih lemah secara jasmaniah, tetapi juga lebih lemah secara moral dan spiritual. Berdasarkan hal tersebut, kaum lakilaki adalah para pengatur kaum perempuan. Meskipun demikian, Adeney (2004: 307) menambahkan bahwa di Indonesia kebanyakan lapangan pekerjaan telah terbuka untuk kaum perempuan; perempuan pun telah bekerja berdampingan dengan lakilaki, akan tetapi modernisasi mendatangkan 
kemunduran dalam fungsi sosial dan ekonomi keluarga. Kaum perempuan didorong untuk mengambil bagian dalam semua kehidupan publik. Perempuan-perempuan yang terjun ke dalam ranah publik ini menderita kerugian yang jelas. Selain mereka harus memenuhi tuntutan-tuntutan dari pekerjaan mereka yang dibayar, mereka juga harus menjalankan semua fungsi tradisional sebagai ibu rumah tangga. Akibatnya baik keluarga maupun pekerjaan menjadi kurang tertangani; dan kaum perempuan mempunyai terlalu banyak pekerjaan. Pola seperti ini sedang tumbuh di Indonesia.

Di sisi lain, Adeney (2004: 296) menjelaskan bahwa masyarakat tradisional Barat juga membatasi sepenuhnya kaum perempuan pada kawasan rumah tangga dan keluarga. Meskipun demikian, tidak ada pandangan "Barat" yang seragam mengenai peran perempuan. Karena semua peran sosial, ekonomi, dan politik kaum laki-laki juga dilakukan oleh kaum perempuan dalam pelbagai macam kebudayaan, maka sangat mungkin bahwa kebudayaan dan sosialisasi adalah penyebab utama perbedaanperbedaan itu. Goode seperti dikutip dalam Kusumastuti (2007: 151) menyebutkan bahwa laporan hasil penelitian dari Prancis, Jerman, dan AS menyatakan adanya hubungan antara kedudukan kelas dan kekuasaan sang laki-laki. Di sini terlihat adanya pertentangan. Terhadap strata yang lebih rendah suami cenderung menuntut kekuasaannya hanya karena ia seorang laki-laki. Terhadap strata yang lebih tinggi, laki-laki lebih sedikit menunjukkan kekuasaan patriarkalnya, sedikit kemungkinan istri mereka bekerja, dan jika mereka itu bekerja mereka hanya menyumbangkan bagian yang kecil saja pada keseluruhan pendapatan keluarga.

Tujuan penelitian ini untuk menemukan model konstruksi makna peran dan posisi perempuan indonesia pelaku kawin campur. Peneliti ingin melihat bentuk-bentuk pemaknaan perempuan Indonesia mengenai peran gender dalam kehidupan berumah tangga lintasbudaya dan faktor-faktor pembentuk pemaknaan tersebut.

\section{Metode Penelitian}

Penelitian menggunakan teknik snowball sampling dalam proses pengambilan informan, seperti yang dipaparkan oleh Bungin (2007: 77) teknik ini digunakan apabila peneliti tak tahu siapa yang memahami informasi objek penelitian. Melalui proses perkenalan dan pendekatan peneliti dengan sebuah komunitas online yang beranggotakan para pelaku kawin campur di situs jejaring sosial Facebook, peneliti berkenalan dengan seorang staf admin komunitas tersebut yang kemudian memberikan akses perkenalan dengan para informan untuk penelitian ini. Semua proses awal perkenalan dengan para informan berlangsung melalui media yang ada, seperti melalui pesan singkat dan telpon. Semua informan penelitian merupakan bagian dari komunitas online tersebut yang bernama KKC (Komunitas Kawin Campur).

Staf admin KKC yang peneliti kenal terlebih dahulu berperan sebagai gatekeeper yang menunjukkan kepada peneliti siapa saja orang yang dapat diwawancarai sehubungan dengan objek penelitian yang ada. Dari proses perkenalan itulah peneliti berhasil bertemu dengan 11 calon informan. Mereka disebut sebagai calon informan karena meski- 
pun mereka bersuamikan laki-laki bule yang merupakan inti dari penelitian - latar belakang asal-usul suami pun harus turut menjadi pertimbangan, yakni negara asal sang suami. Seperti yang telah disebutkan dalam pendahuluan artikel ini bahwa yang dimaksud dengan laki-laki bule dalam penelitian ini tidak hanya ditunjukkan dengan ciri-ciri fisik yang menandakannya sebagai seorang Kaukasia, tapi juga asal negara laki-laki bule tersebut harus merupakan bagian dari klasifikasi negara-negara Barat menurut definisi T.T.Anh (1984:5), yakni negara-negara Eropa Barat, Amerika Serikat, Kanada, Australia, dan Selandia Baru. Ada 11 calon informan, namun yang berhasil memenuhi klasifikasi yaitu 7 informan. Penelitian ini pun dilakukan dengan melibatkan ketujuh informan tersebut.

Adapun ketujuh informan tersebut adalah (1) Mary, perempuan keturunan Madura yang bersuamikan orang Amerika (lima tahun menikah); (2) Lydia, perempuan Jawa yang bersuamikan orang Inggris (tujuh tahun menikah); (3) Sandra, perempuan Batak yang bersuamikan orang Amerika (lima tahun menikah); (4) Rini, perempuan Betawi yang bersuamikan orang Australia (sembilan tahun menikah); (5) Nana, perempuan Jawa yang bersuamikan orang Selandia Baru (sembilan tahun menikah); (6) Erni, perempuan Jawa yang bersuamikan orang Prancis (19 tahun menikah); dan (7) Suci, perempuan Aceh yang bersuamikan orang Inggris (11 tahun menikah).

Proses pengumpulan data dalam penelitian ini menggunakan teknik wawancara mendalam dan kegiatan observasi. Kegiatan wawancara mendalam dilakukan dengan menggunakan pedoman yang berisi garis besar pertanyaan yang berhubungan langsung dengan objek penelitian. Wawancara mendalam dilakukan sebanyak empat sampai lima kali terhadap setiap informan dan berlangsung secara tatap muka. Peneliti berkesempatan untuk mewawancarai suami dari setiap informan sebanyak satu kali pertemuan dalam rangka mengkonfirmasikan validitas data. Setiap pertemuan wawancara berlangsung selama satu hingga dua jam. Selanjutnya, setelah pertemuan-pertemuan tersebut peneliti pun beberapa kali melakukan wawancara melalui telpon saat menemukan data yang masih kurang atau belum lengkap. Kegiatan observasi peneliti lakukan saat peneliti diberi kesempatan untuk berkunjung ke tempat tinggal informan. Pada kunjungan tersebut peneliti berkesempatan mengamati proses interaksi yang berlangsung antara informan penelitian dan suaminya dalam kehidupan keseharian mereka. Hasil pengamatan tersebut kemudian peneliti catat sebagai bagian dari data penelitian. Nama semua informan dalam penelitian ini disamarkan untuk menjaga konfidensialitas mereka.

\section{Hasil Penelitian dan Pembahasan}

Pada dasarnya, konsep peran itu lahir dari pembagian kerja yang yang terdapat dalam pelembagaan seperti yang disebutkan oleh Berger dan Luckmann dalam Teori Konstruksi Sosial atas Realitas. Berger \& Luckmann (1966) berpendapat bahwa peran merupakan hasil konstruksi sosial atas realitas kehidupan pelembagaan yang ada. Peran mewujudkan pelembagaan yang bisa dilakoni oleh sekumpulan orang, dan telah menjadi bagian dari kehidupan sosial itu sendiri. 
Tipologi peran merupakan bagian penting dari pelembagaan perilaku, dimana pengalaman individu melalui perannya dalam kehidupan sehari-harilah yang mewujudkan lembaga-lembaga perilaku tersebut. Individu berpartisipasi dalam dunia sosialnya dengan memaknai dan memainkan perannya. Internalisasi perannya dalam dunia sosial menjadikan dunia tersebut terasa nyata bagi individu (Berger \& Luckmann, 1966: 99-100).

Peran gender dalam sebuah masyarakat pada dasarnya merupakan konstruksi masyarakat itu sendiri melalui objektifikasi yang mereka lakukan. Sebuah konteks yang dibentuk atas dasar konstruksi makna bersama mengenai konsep peran. Jika perempuan berpikir bahwa kodratnya adalah mengurus rumah tangga dan laki-laki beranggapan bahwa kodratnya adalah menjadi tulang punggung ekonomi keluarga, maka anggapan dan pemikiran tersebut tidak tumbuh atau muncul dengan sendirinya. Berger \& Luckmann (1966: 121) menyebutnya sebagai bentuk reifikasi, yakni pemahaman produk-produk kegiatan manusia dengan cara seolah-olah hal itu bukan produk manusia. Reifikasi mengimplikasikan bahwa manusia mampu melupakan kenyataan bahwa ia sendirilah yang telah menghasilkan dunia manusiawi dan selanjutnya bahwa dialektika antara manusia, yang memproduksi, dan produknya sudah hilang dalam kesadaran.

Pemahaman peran gender dalam sebuah masyarakat yang disebut dengan kodrat atau takdir sebenarnya merupakan bentuk objektifikasi manusia itu sendiri. Berger dan Luckmann (1966) pun menegaskan bahwa begitu sebuah dunia sosial yang objektif tercipta, maka kemungkinan reifikasi tidak akan pernah jauh darinya. Objektivitas dunia sosial berarti bahwa ia dihadapi oleh manusia sebagai sesuatu yang berada di luar dirinya. Melalui reifikasi, dunia lembagalembaga tampak melebur dengan dunia alam. Ia menjadi keharusan dan takdir, dan dihayati seperti itu dengan rasa gembira atau sedih, tergantung keadaannya. Hal ini sejalan dengan salah satu keyakinan paham feminis liberal bahwa ketimpangan antara lelaki dan perempuan dikonstruksi secara sosial (socially constructed), dan tidak ada dasarnya dalam "alam" atau "kodrat" (dalam Ritzer \& Goodman, 2010: 421). Demikian halnya dengan peran gender dalam sebuah budaya atau masyarakat.

Pemahaman peran gender masyarakat Indonesia berbeda dengan masyarakat Barat. Hal ini termanifestasi dalam cara suami bule memperlakukan istri Indonesianya sebagai seorang istri, seorang perempuan, dan seorang individu. Menurut kaum feminis liberal, tatanan gender ideal adalah kebebasan individu untuk memilih gaya hidup yang paling cocok untuk dirinya sendiri dan pilihan itu harus diterima dan dihormati oleh istri atau suami (Ritzer dan Goodman, 2010: 426). Hasil penelitian menunjukkan bahwa semua informan penelitian mengaku diperlakukan setara oleh suami. Setara dalam arti bahwa suami bersedia berbagi tanggung jawab dalam urusan rumah tangga dan anak. Informan penelitian pun mengaku bahwa suami memberi mereka kebebasan untuk bekerja jika mereka ingin bekerja, tetapi suami tidak pernah menuntut mereka untuk bekerja 
dan menghasilkan uang. Peneliti melihat bahwa para suami informan menerapkan apa yang kurang lebih dimaksudkan oleh konsep feminis liberal dalam kehidupan seharihari. Para suami membebaskan informan untuk memilih gaya hidup mereka sendiri. Tidak hanya diberi hak untuk bekerja, dalam kehidupan berumah tangga sehari-hari pun informan penelitian mengaku bahwa sang suami tidak pernah menuntut untuk dilayani.

Informan penelitian melalui interaksinya dengan suami dalam kehidupan perkawinannya kemudian mendefinisikan sendiri peran dan posisinya sebagai perempuan dalam keluarga dan kehidupan bermasyarakat. Hasil penelitian menunjukkan bahwa pendefinisian peran dan posisi diri informan dalam keluarga ini sejalan dengan prinsip kesetaraan yang diberlakukan oleh suami yang terbagi atas empat pemaknaan kesetaraan yang berbeda, yakni Kesetaraan Parsial, Kesetaraan Kodrati, Kesetaraan Mutlak, dan Kesetaraan Pragmatis. Pemaknaan akan peran dan posisi diri informan penelitian dalam keluarga dan masyarakat ini peneliti rangkum dalam model berikut:

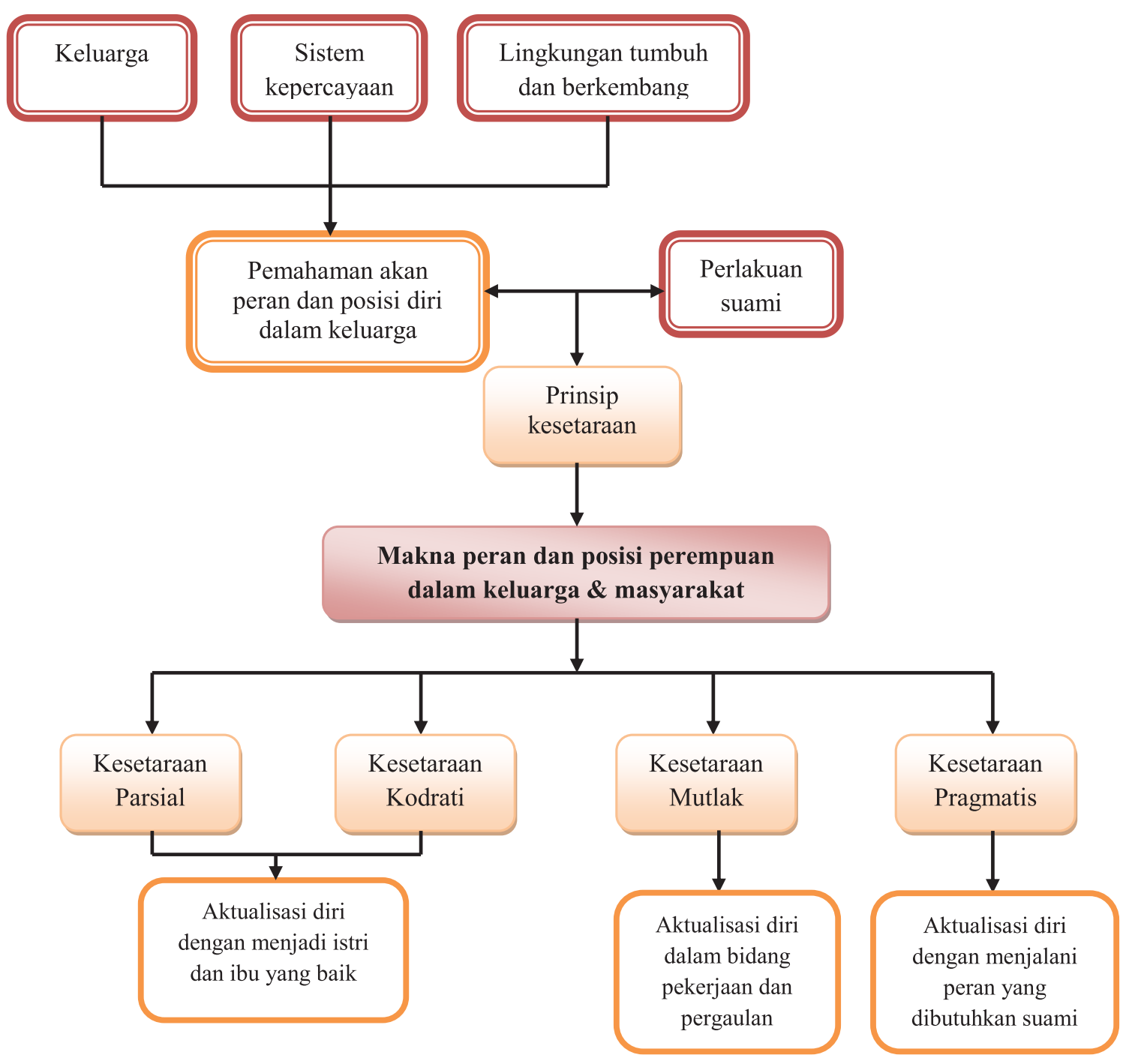

Gambar 1. Model Konstruksi Makna Peran dan Posisi Perempuan dalam Keluarga dan Masyarakat bagi Perempuan Indonesia Pelaku Kawin Campur

Sumber : Data Peneliti 2017 
Gambar 1 menunjukkan bahwa sebelum menikah pemahaman informan akan peran dan posisinya dalam keluarga telah dibentuk oleh keluarganya, sistem kepercayaan, dan lingkungannya untuk tumbuh dan berkembang. Konsep mengenai peran tersebut kemudian berevolusi dan berkembang setelah informan berinteraksi dengan sang suami yang menjunjung prinsip kesetaraan dalam kehidupan perkawinan mereka sehari-hari. Informan penelitian kemudian mengadopsi prinsip kesetaraan yang diterapkan oleh suami tersebut dan mengembangkan pemaknaan dan konsepnya sendiri mengenai peran dan posisinya dalam keluarga dengan berbasis pada prinsip kesetaraan suami. Pada gilirannya, sejalan dengan waktu, informan memiliki konsep dan pemahaman yang utuh mengenai peran dan posisinya sebagai perempuan dalam keluarga dan masyarakat sejalan dengan prinsip suami yang menjunjung kesetaraan dalam berumah tangga, yakni sebagai yang setara parsial, setara kodrati, setara mutlak, dan setara pragmatis. Pemahaman yang utuh tersebut tercapai melalui proses internalisasi subjektif informan terhadap realitas objektif kehidupan perkawinan beda budaya yang dijalaninya.

Hasil penelitian menunjukkan bahwa tiga dari tujuh informan penelitian - Lydia, Sandra, dan Suci - memaknai peran dan posisinya dalam keluarga sebagai yang setara parsial. Informan penelitian dalam kategori ini paham betul akan kodratnya sebagai seorang perempuan dan hanya menuntut kesetaraan dalam hak bekerja. Meskipun sang suami memperlakukannya dengan prinsip kesetaraan yang sebenarnya, yakni bersedia berbagi semua tanggung jawab dalam kehidupan berumah tangga dan memberikan kebebasan bagi istri untuk bekerja, bagi informan yang setara parsial tanggung jawab mengurus rumah tangga, suami, dan anak telah merupakan kodratnya dan tanggung jawabnya sebagai perempuan yang telah menikah. Kesetaraan bagi informan yang setara parsial adalah kesamaan hak untuk bekerja dan menghasilkan uang, sementara pekerjaan rumah atau kegiatan mengurus dan melayani suami memang harus mereka lakukan meskipun suami tidak pernah meminta atau bahkan menuntut mereka melakukan hal tersebut. Seperti yang diutarakan oleh Suci:

"Memang ada hal-hal seperti urusan anak, rumah, yang lebih ditekankan kepada istri gitu, tapi saya saja yang istri seorang warga negara asing mengetahui itu bukan hanya wajib dilakukan oleh istri, tapi karena kodratnya kita itu. Saya sangat bersyukur karena punya partner bule yang notabene menganggap itu kewajiban bersama, tanggung jawa bersama, tapi saya dididik orang tua saya bahwa mengurus anak, rumah, bersihin rumah itu kan sudah hal-hal yang rutin, jadi nggak perlu kita terlalu berkicau "ah saya capek ngurusin rumah" no, itu sudah jadi adat bagi saya."

Sandra pun berpendapat demikian. Bagi Sandra peran perempuan adalah menyediakan segala hal yang menjadi kebutuhan sang suami, anak, dan rumah tangganya. Sandra selalu merasa bersalah saat menemukan suaminya menyiapkan sarapan sendiri setiap paginya. Sedangkan suami tidak pernah merasa itu sebuah masalah. Bagi suami, selama ia masih bisa mengerjakannya sendiri, ia tidak merasa perlu meminta Sandra untuk melakukannya.

Sementara memahami kodratnya sebagai seorang perempuan dengan segala tanggung jawab penuh akan kebutuhan rumah tangga, 
suami, dan anak, informan penelitian setara parsial hanya menginginkan satu hal dari suaminya, yakni hak untuk juga bekerja dan menghasilkan uang. Kesetaraan dalam definisi mereka adalah setara dalam hal mendapatkan hak untuk bekerja. Berikut adalah pendapat Sandra:

“.....gue pengen hidup itu produktif, gue pengen anak gue juga bekerja, jadi ibarat kata gue nggak nadah sama suami. Walaupun gue udah nikah nanti gue tetap harus kerja, kecuali gue punya anak, gue minta break, selama tiga tahun, selama tiga tahun itu gue fokus. Karena kan gue belajar dari nyokap gue, tiga tahun itu masamasa perkembangan, gue nggak mau lepas anak itu dari tangan gue. Gue nggak mau anak gue dididik sama babysitter...."

Pada kehidupan bermasyarakat informan penelitian yang setara parsial mencapai aktualisasi diri dengan berusaha menjadi istri dan ibu yang baik bagi keluarganya. Informan menginternalisasikan perannya sebagai yang bertanggung jawab penuh atas rumah tangga dan keluarga yang memiliki posisi setara dengan suami dalam mengambil keputusan apa pun yang berkaitan dengan kepentingan bersama.

Hasil penelitian menunjukkan bahwa dua dari tujuah informan - yakni Nana dan Erni memaknai peran dan posisinya dalam keluarga sebagai yang setara kodrati. Bagi informan penelitian yang setara kodrati, masingmasing suami dan istri memiliki perannya, dan perannya sebagai seorang istri adalah bertanggung jawab atas semua kebutuhan rumah tangga, suami, dan anak. Informan yang setara kodrati berpandangan bahwa suami dan istri menjalankan perannya masingmasing sebaik mungkin. Bagi yang setara kodrati, sebagai perempuan yang berkeluarga mereka mendedikasikan hidup sepenuhnya untuk mengurusi rumah tangga, suami, dan anak. Pemahaman mereka akan kodrat mereka sebagai perempuan sama dalamnya dengan pemahaman informan penelitian yang setara parsial mengenai kodrat perempuan, namun mereka tidak pernah merasa bekerja sebagai tujuan hidup atau sesuatu yang mereka inginkan setelah menikah. Tugas bekerja dan mencari uang bagi mereka adalah peran suami. Informan ini berasal dari keluarga yang memegang teguh kodrat peran suami dan istri tersebut. Bagi informan penelitian yang setara kodrati, kehidupan setelah menikah sepenuhnya adalah seputar mengurus suami dan anak. Menurut mereka itu adalah suatu bentuk pekerjaan. Seperti yang diutarakan oleh Nana:

"Kan untuk memanage rumah tangga itu peran perempuan paling penting, karena kan laki-laki bisanya kerja doang, biasanya kalau ngurusin rumah tangga - kalau semuanya suami kan, dia perlu istri kan, dia perlu wanita kan, peran penting lah. Di rumah itu lebih banyak kerjaan loh daripada di luar."

Hal senada pun dinyatakan oleh Erni:

"Peran perempuan ya sebagai ibu, sebagai istri, tugasnya ibu dan tugasnya istri. Sebagai ibu ya bertanggung jawab sama rumah dan anak-anak, sebagai istri ya saya bertanggung jawab sama suami saya."

Suami memberi mereka kebebasan untuk menentukan apa yang ingin mereka lakukan, bagi informan penelitian yang setara kodrati urusan anak dan keluarga tetaplah yang utama. Pemahaman mereka akan peran mereka dalam keluarga tidak membuat mereka merasa berada di bawah suami atau merasa inferior. Mereka mengungkapkan bahwa perlakuan suami yang menyetarakan posisi mereka membuat mereka menyadari bahwa posisi mereka dengan suami adalah sama dalam keluarga, sama-sama memiliki kekuatan dalam segala 
urusan yang berhubungan dengan keluarga. Saat ditanya mengenai kemungkinan bekerja dan berkarier kedua informan lebih memilih untuk memfokuskan diri mengurusi anak dan suami. Bagi Erni dan Nana, selama suami masih memberi mereka kesempatan untuk berkumpul bersama teman-teman dan bersosialisasi, mereka tidak pernah merasa terbebani oleh pekerjaan mengurus rumah tangga. Informan yang setara kodrati mencapai aktualisasi dirinya dengan menjadi istri dan ibu yang baik bagi keluarganya karena fokus utama mereka adalah keluarga.

Satu-satunya informan penelitian yang masuk dalam kategori ini adalah Mary. Mary memaknai peran dan posisinya dalam keluarga sebagai yang setara dengan sang suami, persis seperti prinsip kesetaraan yang diterapkan oleh sang suami. Mary besar dalam lingkungan keluarga yang tidak menganut pandangan konvensional mengenai kodrat peran suami dan istri dalam keluarga. Sejak kecil orangtua Mary membiasakannya tumbuh bebas menentukan pilihan untuk menjadi apa yang ia mau. Selain itu, dalam lingkungan pergaulan Mary yang seringkali banyak dikelilingi oleh teman-teman bule, Mary mengadopsi paham kesetaraan yang sebenar-benarnya antara perempuan dan laki-laki. Mary juga berkesempatan untuk mengenyam pendidikan di luar negeri dengan budaya Barat yang kental akan paham kesetaraan tersebut. Sebagai individu berpendidikan tinggi, berpengalaman hidup di luar negeri dengan lingkungan pergaulan yang selalu dipenuhi oleh bule bahkan sebelum bertemu sang suami, Mary mengembangkan cara berpikir yang berbeda dari kebanyakan perempuan Indonesia mengenai peran perempuan setelah menikah. Mary berpandangan bahwa pernikahan adalah sebuah bentuk partnership. Segalanya harus seimbang antara tanggung jawab suami dan istri. Menurut Mary:“....kalau gue sih konsepnya dari dulu emang yang sebagai partner ya....partnership aja pokoknya....equal sih kalau gue bilang...."

Pada kehidupan sehari-hari Mary tidak merasa adanya obligasi untuk melayani atau mengurusi suami. Mary merasa setara dengan suami dalam segala hal, meliputi urusan rumah tangga, anak, dan hak bekerja untuk menghasilkan uang. Seperti pemaparan Mary berikut:

"Kalo aku sih sama dia (suami) aku bilangnya kita partner....., karena gue juga kadang males ngurusin makan dia, dia juga don't mind kok, dia biasa bikin sendiri makanannya atau keluar cari makan di luar, yang kayak gitu-gitulah....."

Berdasarkan hal tersebut, konsep kesetaraan bagi informan penelitian yang setara mutlak adalah yang mencakup segala aspek dalam kehidupan berumah tangga. Suami dan istri saling berbagi tanggung jawab yang sama besar dalam kehidupan berumah tangga mereka. Maka, bagi Mary bentuk aktualisasi dirinya dalam kehidupan bermasyarakat tidak hanya bekerja, melainkan juga bersosialisasi. Statusnya sebagai istri dan ibu tidak banyak mengubah pola pergaulan sebelumnya.

Rini, satu-satunya informan penelitian yang pragmatis, beranggapan bahwa hidupnya dan keberadaannya hanya berkaitan dengan masa kini. Pahamnya akan kesetaraan yang diterapkan oleh suami adalah bagaimana suami dan istri masing-masing memenuhi perannya sebagaimana yang dibutuhkan oleh pasangan mereka. Perannya sebagai perempuan, sebagai 
istri pun berorientasi pada kepentingan praktis masa kini dan kebutuhan pasangannya. Saat ini Rini tengah menyelesaikan pendidikannya sebagai mahasiswa tahun akhir sebuah perguruan tinggi swasta di Jakarta. Keputusan Rini melanjutkan kuliah pun karena didorong oleh sang suami. Rini sama sekali tidak memiliki gambaran mengenai masa depannya, tidak memiliki cita-cita dan ambisi. Dia cukup senang dengan apa yang dimilikinya saat ini. Bagi Rini yang terpenting adalah apa yang terjadi hari ini, urusan besok atau masa depan ia serahkan pada waktu. Saat ini yang terpenting baginya adalah menyelesaikan kuliah seperti yang diinginkan oleh suaminya dan menjadi istri yang baik dengan selalu berusaha berada di sisi sang suami. Ketika menyinggung kemungkinan untuk bekerja atau berkarier, Rini berkomentar:

“.......kadang orang suka ngiri sama aku 'gue ngiri deh sama lo rin, lo nggak disuruh kerja, lo tinggal di rumah aja, lo mau ngapain juga terserah! Lah, emang harusnya gimana dong?"

Rini memaknai perannya sebagai seorang istri tergantung pada kondisi dan orientasi waktu masa kini, pada aspek manfaatnya dalam kehidupan sehari-hari. Bagi yang setara pragmatis, perannya sebagai individu bergantung pada kebutuhan pasangannya akan dirinya. Dia akan melakukan apapun untuk memenuhi kebutuhan suaminya. Saat ini sebagai istri Rini hanya ingin menjadi istri yang baik bagi suami, seperti yang suaminya inginkan. Jika nanti memiliki anak, Rini pun hanyainginmenjadi ibuyangbaikbagi anaknya kelak. Rini mengaktualisasikan dirinya dalam kehidupan bermasyarakat dengan selalu berusaha menjadi istri yang baik bagi sang suami, selalu berusaha tampil sebaik mungkin - sebisa mungkin - sesuai dengan keinginan suami. Hal ini ditunjukkan Rini dengan selalu membiarkan suami memilihkan baju dan sepatu yang harus dibelinya saat berbelanja. Rini merasa perlu merepresentasikan dirinya sebaik mungkin sebagai seorang istri. Informan menginternalisasikan perannya sebagai seorang istri berdasarkan kebutuhan suaminya yang berorientasi pada masa kini.

Informan tidak pernah berbicara mengenai kodrat dan tanggung jawab. Informan hanya berbicara mengenai perannya yang terbentuk karena kebutuhan suami. Dia akan melakukan apa yang diminta suami dan tidak melakukan apa yang tidak diinginkan suami. Orientasi informan ada pada kebutuhan suaminya. Informan pun meletakkan kepercayaan sepenuhnya dan nasibnya pada suami, sehingga segala keputusan yang berhubungan dengan kepentingan bersama diserahkannya pada suami. Ketergantungan informan yang tinggi terhadap keberadaan suami mungkin akan membawa dampak negatif bagi dirinya sendiri saat sang suami tiada suatu hari nanti. Ketergantungan inilah yang membuat informan termasuk dalam kategori setara pragmatis, yang memainkan perannya hanya karena harus melengkapi peran yang lain, yakni suami dan istri.

\section{Simpulan}

Peran gender dalam sebuah perkawinan lintasbudaya melibatkan negosiasi yang panjang melalui interaksi-interaksi yang terjalin antara suami dan istri. Bagaimana dua cara pandang dari dua latar belakang budaya yang berbeda saling melebur, melengkapi, kemudian berkembang menjadi pemaknaan "baru" atas peran dan posisi perempuan 
dalam kehidupan berumah tangga. Isu peran gender mungkin merupakan satu dari banyak isu kompleks lainnya dalam perkawinan lintasbudaya, namun bukan berarti isu tersebut tidak bisa diatasi. Pada konteks inilah komunikasi memegang peran penting.

Komunikasi dua arah dengan bahasa yang sama-sama dimengerti oleh kedua belah pihaklah yang memungkinkan negosiasi pemaknaan peran gender dalam kehidupan perkawinan lintas budaya. Pada gilirannya, kedua belah pihak akan bertindak sesuai dengan harapan pasangannya masing-masing dalam rangka menyesuaikan diri satu sama lain.

\section{Daftar Pustaka}

Adeney, Bernard T. (2004). Etika Sosial Lintas Budaya. Yogyakarta: Kanisius.

Anh, T.T. (1984). Nilai Budaya Timur dan Barat Konflik atau Harmoni? ( J. Yap Pereira Penerjemah). Jakarta : PT. Gramedia.

Berger, P. L., \& Luckmann, T. (1991). The Social Construction of Reality: A Treatise in the Sociology of Knowledge. Penguin UK.

Blumer, Herbert. (1969). Symbolic Interactionism: Perspective and Method. New Jersey: Prentice-Hall.
Gudykunst, William \& Young Yun Kim. (1992). Communicating with Strangers. New York: McGraw-Hill.

Mead, G. H. (1934). Mind, self and society (Vol. 111). University of Chicago Press.: Chicago.

Mulyana, Deddy. (2008). Metodologi Penelitian Kualitatif. Bandung: Remaja Rosdakarya. \& Solatun. (2008). Metode Penelitian Komunikasi. Bandung: Remaja Rosdakarya.

Ritzer, G., \& Goodman, D. J. (2010). Teori Sosiologi Dari Teori Sosiologi Klasik Sampai Perkembangan Mutakhir Teori Sosial Postmodern. Yogyakarta: Kreasi Wacana.

Samovar, Larry A., Richard E. Porter, \& Edwin R. McDaniel. Communication Between Cultures. Belmont: Thomson Higher Education.

West, Richard \& Lynn H. Turner. (2006). Understanding Interpersonal Communication. Belmont: Thomson Higher Education.

\section{Sumber Lain}

S.R., Indah Permata Kusumastuti. (2007). Penetrasi Sosial Pasangan Menikah Berbeda Budaya (Studi Kasus Pasangan Menikah Amerika dengan Indonesia). Fakultas Ilmu Sosial dan Ilmu Politik Universitas Indonesia (www.lib.ui.ac.id), Jakarta. 